\title{
Motivation to Learn English Language: A Study of Shah Abdul Latif University, Khairpur, Sindh
}

\author{
Ajab Ali Lashari ${ }^{1}$, Ghulam Mustafa Mashori ${ }^{2}$, Abdul Malik Abbasi ${ }^{1} \&$ Quratulain Talpur ${ }^{3}$ \\ ${ }^{1}$ Sindh Madressatul Islam University, Karachi, Sindh, Pakistan \\ ${ }^{2}$ Shah Abdul Latif University, Khairpur, Sindh, Pakistan \\ ${ }^{3}$ Mehran University of Engineering and Technology, Shaheed Zulfiqar Ali Bhutto Campus, Khairpur, Sindh, \\ Pakistan \\ Correspondence: Ajab Ali Lashari, Sindh Madressatul Islam University, Karachi, Sindh, Pakistan. E-mail: \\ ajablashari@smiu.edu.pk
}

$\begin{aligned} & \text { Received: August 21, } 2017 \\ & \text { Accepted: September 24, } 2017 \quad \text { Online Published: October 25, } 2017 \\ & \text { doi:10.5539/ijel.v8n1p15 }\end{aligned}$ URL: https://doi.org/10.5539/ijel.v8n1p15

\begin{abstract}
The present study aims to investigate the motivational factors which are directly involved in learning English language among Bachelor of Science (B.S) first year undergraduate students of Institute of English Language and Literature, Shah Abdul Latif University, Khairpur, Sindh Pakistan. The study focuses on intrinsic and extrinsic motivation factors, which motivate students to learn English language. The questionnaire has been administered among students $(\mathrm{N}=70)$ which are based on 30 Likert scale items. Attitude Motivation Test Battery/AMTB (Gardner, 2004 English version) has been used in this regard. SPSS has been used to quantify the data. The semi-structured interview has been conducted by using purposive sampling for in-depth study from $(\mathrm{N}=6)$ students. The results reveal that the students have extrinsic reasons as dominant factors for motivation to learn the target language. The dominant extrinsic factors which were investigated among the students are to get a good job and to qualify exams. The intrinsic factors such as learning English for developing self-image and communication skills in English with proficiency in their daily routine work are responsible for motivating students to learn English language.
\end{abstract}

Keywords: intrinsic motivation, extrinsic motivation, motivation, attitudes, English as second language

\section{Introduction}

Motivation research has remained a great importance for learning target language since 1990s. Researchers agree that it is a driving force to attain higher life-long goals as well as learning target language. English language has its dominant status since it is used globally as a source of communication and a tool to communicate with the whole world through social media. English is a widely used language in educational institutions; where courses are offered; tests are taken and lectures are delivered in only English language. Speaking English fluently, getting self-identity/ exposure and getting a good job or living with learning is the dream of every student. Motivational research has played an important role in the field of psychology as well as a second language learning. It has opened the new vistas for the researchers for understanding of the target language and to facilitate learners for their higher achievements in the attainment of the second language. Gardner (2005) defines that efforts are made to achieve certain goals or to make choices is the result of motivation. Dörnyei (1998) argues that a second language can be learnt successfully with sufficient amount of motivation and it is a key factor in this regard which has been recognized by teachers as well as researchers. Gardner (2005) believes that motivated individuals have always strong reasons to pursue their goals. They always perform those tasks with fun and the reasons for the pursuit of their goals are called motives.

Dörnyei (2001) states that intrinsic motivation energizes individuals internally to achieve the highest goals of life. Deci, Olafsen, and Ryan (2017) argue that intrinsic motivation develops interest and makes it fun to enjoy spontaneous experience for the activity to get a reward in short span of time.

Dörnyei and Ushodia (2014) define that intrinsic motivation is the total sum of preferences, comforts, and ambitions whereas extrinsic motivation is the sum of honor, particularly job and other incentives.

The research study intends to answer the questions as follows: 
1) What are the motivational factors responsible for learning English language?

Sub Questions:

(1) How do intrinsic factors help in learning target language?

(2) How do extrinsic key factors help in learning target language?

(3) Is there a positive attitude of students for learning the target language?

\section{Literature Review}

Motivational research has a long history of 50 years as a driving force for the governing behaviors of individuals. Boo, Dörnyei, and Ryan (2015) conducted a survey in which they found that the research studies which have been conducted in between 2004 to 2014 on L2 motivation, 70\% of research studies are based on motivation research. Dörnyei (1998) states that human behavior is governed by sufficient motivation and it leads to the proper directions. Dörnyei (2005) believes that motivation in academia has a great role which is acknowledged by teachers and students in higher success rates. Richards \& Schmidt (2002, as cited in Wolf, 2013) propose that the tasks can be completed with only presence of motivation inside individuals. Brown (2007) believes that the learners being motivated can lead them to get the success in academic career. Dörnyei (2001) asserts that intrinsic motivation is a willing force that energizes someone to pursue something with self-interest. Cheng and Dörnyei (2007) argue that the achievement of a target language can be possible with only motivation that is recognized as a key factor to justify their efforts.

Gardner (1985) states that the positive attitudes are the key factor for the construct of motivation in a second language. Dörnyei and Ushioda (2011) find "intrinsic and extrinsic motivation models remained hot subjects. Where internal factors are desires, interests, and the wishes would play a major role whereas extrinsic factors in which rewards, jobs and some incentives play their role" (p. 38). Oroujlou and Vahedi (2011) define that learning language can be determined with proper motivation, a set of positive opinions and attitudes. Deci and Ryan $(1985,2002)$ focus on intrinsic and extrinsic motivation as regulating factors towards the life-long goals.

Dörnyei (2005) argues that intrinsic motivation inside individuals always helps in providing satisfaction for the individuals and providing pleasure for the tasks performed for the experience. While extrinsic motivation helps in providing satisfaction in the attainment of a reward or getting a job. Deci and Ryan (2000) state that the performing some tasks with fun, enjoyment and interest that indicate intrinsic motivation factors. "Intrinsic is an autonomous motivation. It refers to activities for which the motivation lies in behavior itselfand when intrinsically motivated, it is the spontaneous experiences of interest and enjoyment entailed in anactivity that supplies rewards" (Deci, Olafsen, \& Ryan, 2017, p. 21). Shaheen Murtaza and Saeed (2016) find that the students' strong motivation towards learning English is to get a job, a social status and money.

Mari, Pathan, and Shahriar (2011) argue that the students are motivated intrinsically because of their realization to learn English language at university level. Shahriar, Mari, and Umrani (2015) argue that the teacher is an important extrinsic factor for developing motivation among students to learn the target language.

Simming, Anthony, Chana, Chandio, Lashari, and Al-Mamry (2015) find that the students in Pakistan learn English because they are both intrinsically and extrinsically motivated.

Motivation decides and sets the priorities in achieving something and intrinsic and extrinsic motivational factors drive individuals to the direction, while attitudes help develop the force of driving towards the direction.

\section{Methodology}

The study was conducted by using mixed method approach. The participants of the study are undergraduate students of Institute of English Language and Literature Shah Abdul Latif University, Khairpur, Sindh Pakistan. The data were collected through questionnaire and semi-structured interview. For quantitative approach questionnaire was administered among $(\mathrm{N}=70)$ students by using convenience sampling type. The number of male students was $(\mathrm{N}=51)$ and female students $(\mathrm{N}=19)$. For the qualitative study, a semi-structured interview was conducted by using purposive sampling from $\mathrm{N}=6$ students. Data was quantified through SPSS by Mean, Standard Deviation and \% of the responses from the questionnaire. The interview was recorded, transcribed, coded, and interpreted by applying content analysis method. For ensuring the validity of qualitative data, a great care was taken.

Mixed method study is useful and more reliable for in-depth second language learning research. Dörnyei (2007) states that the data analysis and data collection are based on the quantitative and qualitative approach in mixed method research. 
The question items were imported from Gardner's Attitude Motivation Test Battery AMTB (English version, 2004) because it was used an important tool in various contexts for measuring the motivation and attitude. Gardner's ATMB remain more valid and reliable tool to measure motivation research in different contexts. The questionnaire was based on Likert scale and there are 30 question items. 10 questions were selected regarding the intrinsic factors, 10 for extrinsic factors and 10 for attitudinal factors. The options in the questionnaire are "Strongly Disagree" = 1, "Moderately Disagree" =2, "Slightly Disagree"=3, "Slightly Agree"=4, "Moderately Agree" $=5$, "Strongly Agree" $=6$ " as illustrated in Table 2.

\section{Results}

Table 1. Reliability statistics

\begin{tabular}{lll}
\hline Factors & Cronbach Alpha & Question Items \\
\hline Intrinsic Factors & .733 & 10 \\
Extrinsic Factors & .762 & 10 \\
Attitude factors & .787 & 10 \\
\hline
\end{tabular}

Reliability statistics regarding the tool was satisfactory. When Cronbach Alpha value reaches at 0.7 , it indicates the reliability of the tool (Dörnyei, 2007, 2003; Plant, 2010). Creswell (2012) states that Alpha values above 0.7 show acceptability of results. Dörnyei (2007) states that it is sound warning bell if Cronbach Alpha value is less than 0.6. The reliability of the questionnaire shows a positive and a quite satisfactory results. Results for all factors were greater than .7 which shows reliable results.

Table 2. Statistics for intrinsic factors

\begin{tabular}{llll}
\hline & Mean & Std. Deviation & N \\
\hline I strongly wish to speak English fluently. & 5.15 & 1.198 & 70 \\
I have strong desire to get mastery over English language and its all skills. & 4.89 & 1.435 & 70 \\
I feel self-confident when I asked to communicate in English in the class. & 4.62 & 1.375 & 70 \\
Learning English is fun and enjoyment for me. & 4.94 & 1.250 & 70 \\
I want to spend the whole day in learning and speaking English. & 4.21 & 1.520 & 70 \\
I feel happy to devote all time for English class rather than subjects' classes. & 4.44 & 1.461 & 70 \\
I intend to learn English fully in future. & 5.11 & 1.263 & 70 \\
I have strongly desire to get mastery over English to speak like native speakers. & 5.08 & 1.354 & 70 \\
I intend to learn English even it is experienced as toughest task. & 4.76 & 1.488 & 70 \\
When I feel problem in English class I feel confident to know from my English Teachers. & 4.53 & 1.472 & 70 \\
\hline
\end{tabular}

Table 2 reveals that respondents are with good responses in terms of intrinsic motivation factors for learning English language and there is infrequent disagreement to the question statement responses. In response to the statement I strongly wish to speak English fluently is with the highest responses ratio of Mean= 5.15, S.D $=1.198$ in which $61.4 \%$ students show strong agreement which refers to satisfactory responses of students regarding intrinsic motivation factors. In response to the statement "I intend to learn English fully" in which Mean= 5.11, $\mathrm{S} . \mathrm{D}=1.263$ in which $58 \%$ students show strong agreement. The statement "I have strong desire to get mastery over English language and its all skills" is with Mean=4.90, S.D $=1.435$ with $60 \%$ strong agreement responses.

The responses indicate that there is less disagreement to the statements and the interview responses also indicate that they are also intrinsically motivated for learning English language. One of the interviewees mentioned that English language will give them respect and it will give him an identity as an educated person. Another interviewee mentioned the global significance of English language and it is used as a global language so it will help them to communicate with the people globally. Another interviewee shared that when he gets a chance to visit foreign country he will get benefit from English in communicating with the foreigners. Some interviewees also responded that by speaking English language, they will be considered as the educated persons in their community and among their fellows and will be respected as well. Learning English will help them to develop a self-image, that is of great importance among students. This aspect has a great significance for learning the target language and it is a great source of their intrinsic motivation. They intend to get mastery over four skills and they 
strongly desire to be fluent like native speakers in English language.

Table 3. Extrinsic motivation factors

\begin{tabular}{llll}
\hline & Mean & Std. Deviation & N \\
\hline My parents always encourage me to be fluent in English language. & 4.36 & 1.694 & 70 \\
Mastery of English will help me to get a good job. & 5.41 & 1.198 & 70 \\
English teacher has dynamic style for teaching English language. & 5.03 & 1.179 & 70 \\
My parents have made me realize the importance of English language. & 5.06 & 1.238 & 70 \\
My parents bother me to ask for help from teachers if it is required. & 4.47 & 1.491 & 70 \\
Speaking English perfectly will help in getting success in academic career. & 5.09 & 1.271 & 70 \\
My parents show interest in my English class tests scores and performance. & 4.44 & 1.575 & 70 \\
I get motivated and inspired by my English teacher. & 4.77 & 1.342 & 70 \\
Speaking English language will honor me in respect of society. & 4.31 & 1.806 & 70 \\
I am motivated to learn English by my parents as well. & 5.11 & 1.399 & 70 \\
\hline
\end{tabular}

The results show that students have strong extrinsic reasons to learn English language. It seems that extrinsic motivation factors are dominant among the students for learning English language particularly by looking at the statement 2 Mastery over English will help me to get a good job is with Mean = 5.41, S.D $=1.198$ in which 75.5\% students show strong agreement and only $1.4 \%$ disagreement. This indicates that the most common factor among students for learning English is to get a good job.

Another important factor for learning English among students is parental support. The statement ' $I$ am motivated to learn English by my parents as well' is on 2nd rank with Mean=5.11, S.D=1.399 and $64.3 \%$ students show strong agreement to the statement and another statement 4 is also concerned with parental support. With response to the statement 4 my parents have made me realize, the importance of English language is with Mean= 5.06, $\mathrm{S} . \mathrm{D}=1.238$ in which $55.7 \%$ responses have been marked strongly Agree. Parental support is important for students to get success in their academic career. In response to the statement 6 "Speaking English perfectly will help in getting success in academic career" is with Mean $=5.09, \mathrm{~S} . \mathrm{D}=1.271,58.6 \%$ strong agreement responses which indicate that students have the desire to be successful in their academic career. Statement 3 is with $\mathrm{M}=5.03$, $\mathrm{S} . \mathrm{D}=1.179$ and $52.9 \%$ students show strong agreement which specifies that teacher has a significant role in motivating the students for learning English language.

Interview responses are also corroborated with statistical results. All of the interviewees agree that parents are the source of encouragement for learning the target language. One of the interviewees responded to the question saying that she intended to get admission in Zoology department but her father bothered her to get admission in English department which is also of great significance for the development of motivation. The common factor that most of the interviewees shared was strong agreement to get mastery over the target language for a better job. A good job is a strong factor among respondents for their strong motivation. Many respondents shared that their English teacher plays a significant role in developing a motivation for learning English language. Their cooperation and teaching style help them to be motivated for learning the target language.

The results show the significant factors which are the source of motivation for learning English language is for a better job, parental support is also having significant influence over the students learning it. English teacher is of a great worth as well beside job and parental support. They have the self-realization that if they learn English then they will be successful in their professional career which guarantees them to spend their life in terms of the standard life. Table 4 illustrates the quantitative results for attitudinal factors. 
Table 4. Quantitative results for attitudinal factors

\begin{tabular}{llll}
\hline & Mean & Std. Deviation & N \\
\hline It is useless to be present in English class. & 1.54 & .912 & 70 \\
My English class is boring class for me. & 1.90 & 1.194 & 70 \\
I avoid speaking English language. & 2.00 & 1.435 & 70 \\
I don't give proper attention to complete my English class work. & 2.24 & 1.488 & 70 \\
I feel that my fellows laugh when I will speak English in class. & 2.42 & 1.672 & 70 \\
I feel nervous while speaking in English. & 2.20 & 1.538 & 70 \\
When I asked to speak in English I remain calm and don't give a response. & 2.96 & 1.698 & 70 \\
I love to spend too much time on other subjects rather than English subject. & 2.81 & 1.679 & 70 \\
I don't like my English teachers. & 2.57 & 1.682 & 70 \\
English teachers do not teach in an interesting way in class. & 2.31 & 1.584 & 70 \\
\hline
\end{tabular}

Table 4 indicates that the students' attitude towards the target language. The results reveal that students are with a positive attitude for their English class, English teacher, and English as a subject. In response to statement:1 "It is useless to be present in English class is with Mean=1.54, S.D $=.912$ in which $60 \%$ responses are marked on strongly disagreement and $34.3 \%$ responses are Disagree, which indicates the positive attitude of students for learning English language. In response to the statement:8 "I love to spend too much time on other subjects rather than English" with Mean = 2.81, S.D $=1.679$ in which $32.9 \%$ students show disagreement and $25.7 \%$ strong disagreement which reveals that students' positive attitude in spending too much time on English subject. Statement: 3 results indicate that students do not avoid speaking English language in which 47.1 responses show strong disagreement against the statement. Statement:10 also indicates that $45.7 \%$ strong disagreement and 20\% disagreement to the statement indicating that the English teachers teach with an interesting way to the students for development of their language skills. Interview results indicate that students have positive attitudes towards English language because it is used as a global language and has a great significance in everyday life. They like English as a subject and they have a positive attitude for English teachers as well. One of the interviewees shared that English language will give him bright future which is a positive sign for the target language.

\section{Discussion of the Results}

The findings of the study reveal that students have strong motivation to learn English language because of its significance globally. They are fully conscious of the global significance of English language. The responses indicate that learning English language will guarantee their success in future endeavors and they will live a respectable life. The main objectives behind learning English is to get a good job and earn a handsome amount to live up to the standards of life. The students are intrinsically as well as extrinsically motivated and committed to get mastery over the target language and they have a positive attitude for English language as a subject and for the English language teachers. The results of the study show that the students are intrinsically motivated to learn it. They want to get mastery over all skills of English language. The statements 1, 2, 7 and 8 indicate that respondents are motivated to speak English fluently, to master over reading, writing, speaking, and listening skills. They also learn the target language with fun and do not feel any problem to learn it.

The intrinsic factors such as learning English for communication purpose and developing self-image, watching movies and understanding lectures, were dominant for learning the target language, whereas extrinsic factors such as learning English for getting a good job and passing exams were investigated as motivational factors, while students have positive attitudes since English is used globally and those who speak English are considered as the educated people.

In addition to the results of the study, it has been found that there are multiple factors responsible for students' motivation to learn the target language. Reviewing literature review and responses of the students it is pointed out that the students have self-willingness to learn the target language because of various factors such as academic success, reward, respect, identity as an educated person, and the major factor is to get a good job. As the results, factors involved for language learning have been categorized into intrinsic factors, extrinsic factors and attitudinal factors.

First the intrinsic factors for motivating students to learn the target language are various. The responses indicate that the students have self-realization and self-willingness to learn the target language because the target language will give them an identity as an educated person. They are motivated to learn the target language even 
if it is difficult for them, which is also a good sign for motivation towards the target language. They want to be fluent like native speakers to get a respect among the fellows and in their community.

Secondly extrinsic factors for learning the target language are dominant. Respondents through questionnaire and interview responses are common regarding extrinsic factor. The most common factor was learning English for the sake of getting a good job so that they should live better life in terms of the standards of society. The majority of the students belong to rural areas so they wish to have a job after the completion of their degree. Parental support is another dominant factor for learning the target language. Since their parents also expect from their children to be fluent in target language so that they should complete their degrees and could get a better job in order to contribute their family financially. The teacher's role is also of great importance in motivating to the students for the target language. English language teachers can develop motivation for learning the target language through their teaching methods and positive attitudes.

Finally, the findings reveal that the students have a positive attitude towards the target language. The major reasons behind their attitude were the global importance of target language. And English language will develop their identity as an educated man since they have a positive attitude towards the English language teachers and English as a subject.

\section{Conclusion}

The study was conducted on a small scale to investigate the role of motivation for learning English language at Shah Abdul Latif University Khairpur, Sindh, Pakistan. The study has its significance because it has been conducted in local context and the sampling of the study was in majority from rural settings of Sindh. It further highlights students' intrinsic factors, extrinsic factors and attitudinal factors which make the sum of total motivation for learning English language.

The findings of the study discover that the students have self-realization and strong self-willingness to learn English language. The students are rest-assured that learning English language will make them successful in their academic and professional life. They are intrinsically motivated because English language will develop their image and help in understanding the lectures and movies. The most common and dominant extrinsic factor for learning the target language was to get a good job. The students have a positive attitude for the target language due to the global significance of English language and they are encouraged by their parents to learn the target language. Still there is a need to carry out a major study on the role of motivation for learning target language and to address the problems of such students who have less access to other resources of education and job as compared to the students living in urban areas. In addition, the study has a significance since it was conducted in local rural context of Sindh and it will provide better insights in terms of other public-sector universities in Sindh, Pakistan.

\section{References}

Boo, Z., Dörnyei, Z., \& Ryan, S. (2015). L2 motivation research 2005-2014: Understanding a publication surge and a changing landscape. System, 55, 145-157. https://doi.org/10.1016/j.system.2015.10.006

Brown, H. D. (2007). Principles of language learning and teaching. New York: Pearson Publisher.

Creswell, J. W. (2012). Educational Research: Planning, coding and evaluating quantitative and qualitative research. Boston: Pearson.

Deci, E. L., Olafsen, A. H., \& Ryan, R. M. (2017). Self-determination theory in work organizations: The state of a science. The Annual Review of Organizational Psychology, and Organizational Behavior, 4, 19-43. https://doi.org/10.1146/annurev-orgpsych-032516-113108

Dörnyei, Z. (1998). Motivation in second and foreign language learning. Language Teaching, 31, 117-135. https://oi.org/10.1017/S026144480001315X

Dörnyei, Z. (2001). New themes and approaches in L2 motivation research. Annual Review of Applied Linguistics, 21, 43-59. https://doi.org/10.1017/S0267190501000034

Dörnyei, Z. (2005). The psychology of the language learners: Individual differences in second language acquisition: London: Lawrence Erlbaum Associates.

Dörnyei, Z. (2007). Research methods in applied linguistics: Quantitative, qualitative, and mixed methodologies. Oxford: Oxford University Press Publications.

Dörnyei, Z., \& Ushioda, E. (2011). Teaching and researching motivation. Harlow, England: Pearson Publication Limited. 
Gardner, R. C. (1985). Social psychology and second language learning: The role of attitude and motivation. Bedford Square, London: Edward Arnold Publisher.

Gardner, R. C. (2005). Integrative motivation and second language acquisition. Canadian Association of Applied Linguistics/Canadian Linguistics Association. Joint Plenary Talk held at The University of Western Ontario, London, Canada. Retrieved from: http://publish.uwo.ca/ gardner/docs/caaltalk5final.pdf

Oroujlou, N., \& Vahedi, M. (2011). Motivation, attitude, and language learning. Procedia-social and Behavioral Sciences, 29, 994-1000. https://doi.org/10.1016/j.sbspro.2011.11.333

Pathan, H., Shahariar, A., \& Mari, M. A. (2010). Motivation for learning English in Pakistan. ELF, Annual Research Journal SALU, 12, 75-91.

Plant, J. (2011). SPSS survival manual: A step by step guide to data analysis using SPSS for windows (2nd ed.). Sydney: Ligare Sydney Publication Ltd.

Ryan, R. M., \& Deci, E. L. (2000). Intrinsic and extrinsic motivations: Classic definitions and new directions. Contemporary Educational Psychology, 25, 54-67. https://doi.org/10.1006/ceps.1999.1020

Shaheen, A., Murtaza, N., \& Saeed, M. (2016). Students' perceptions about motivating factors related to teachers' behavior at secondary school level. PJERE, 1(1), 15-27.

Shahriar, A., Mari, M. A., \& Umrani, T. (2015). Factors causing L2 motivational change over time: A case study of IR and Physics Department at the University of Sindh. ELF, Annual Research Journal SALU, 17, 23-40.

Simming, I. A., Anthony, E., Channa, M. A., Chandio, A. A., Lashari, A. A., \& Al-Mamary, Y. (2015). Motivation towards learning English as a second language among science undergraduates in Pakistan: A case study of QUEST Pakistan. The Social Science, 6(10), 718-722.

Woolf, A. (2013). Educational Psychology. India: Dorling Kindersely Publisher.

\section{Copyrights}

Copyright for this article is retained by the author(s), with first publication rights granted to the journal.

This is an open-access article distributed under the terms and conditions of the Creative Commons Attribution license (http://creativecommons.org/licenses/by/4.0/). 